\title{
Perception of the Students of Vocational Program, University of Indonesia: The Implementation of Sistem Informasi Prestasi Mahasiswa Universitas Indonesia (SIPRESMA UI)
}

\section{Titis Wahyuni ${ }^{1}$, Dyah Safitri², and Nur Arini Batubara Vera ${ }^{3}$}

${ }^{1}$ Vocational Program in Accounting, Vocational Education Program, Universitas Indonesia, Depok, Indonesia

${ }^{2}$ Vocational Program Information and Document Management, Vocational Education Program, Universitas Indonesia, Depok, Indonesia

${ }^{3}$ Vocational Program hospitalization, Vocational Education Program, Universitas Indonesia, Depok, Indonesia

\section{Abstract}

Corresponding Author:

Titis Wahyuni

titisw2001@gmail.com

Received: 8 June 2018

Accepted: 17 July 2018

Published: 8 August 2018

Publishing services provided by Knowledge $\mathrm{E}$

(c) Titis Wahyuni et al. This article is distributed under the terms of the Creative Commons Attribution License, which permits unrestricted use and redistribution provided that the original author and source are credited.

Selection and Peer-review under the responsibility of the 2 nd ICVHE Conference Committee.
Sistem Informasi Prestasi Mahasiswa Universitas Indonesia (SIPRESMA UI) is an information system used to manage data for non-academic achievements of students enrolled at the University of Indonesia. The output of this system is a diploma supplement. Diploma supplement is a letter describing qualifications or competence of a certificate issued in accordance with applicable regulations as well as to provide information about the achievements and awards achieved by the graduate studies. This is in accordance with the government regulation that requires college academic transcripts issued with accompanying Diploma Supplement. One of its functions is that diploma supplement can be used to assist graduates in finding a job. The purpose of this study is to determine students' perceptions of Vocational Program, University of Indonesia against SIPRESMA UI-whether their knowledge of SIPRESMA is adequate, whether the students know the benefits that can be obtained from the diploma supplement as well as obstacles in the implementation SIPRESMA UI.

The study used a descriptive quantitative method. The results of this study found that $55.03 \%$ of the students quite agreed that they ever heard of SIPRESMA UI, $68.99 \%$ of the students agreed that they knew diploma supplement is important to help them easier to get a job in accordance with the competence of graduates, and $68.42 \%$ of the students agreed that the constraints of the application SIPRESMA UI in vocational program is the lack of the awareness of students to manage personal archive.

Keywords: Vocational Program University of Indonesia, diploma supplement, SIPRESMA UI

\section{S OPEN ACCESS}




\section{Introduction}

Vocational Education Program, University of Indonesia is the only authorized provider of high education diploma at the University of Indonesia. Vocational Education Program aims to prepare students to become experts or professionals who deploy, develop and disseminate technology and art and culture in an effort to improve people's lives, civilization and also at the same time enrich the national culture. In other words, Vocational Education Program, University of Indonesia will produce graduates who are ready to work in the industry. Graduates of Vocational Education Program, University of Indonesia, in addition to having a diploma as an Associate Expert particular field must also have competency/skills as evidenced by a certificate of competency/skills in accordance with their respective fields formalized exerts Companion Certificate Diploma. This is in accordance with the Regulation of the Minister of Education and Culture No. 81 Year 2014 concerning Diploma, Certificate of Competency and Professional Certificate of Higher Education, in Article 5, which states that the diploma awarded to university graduates with at least the Academic Transcripts and Certificate Companion Diploma.

Letter Companion Certificate or Diploma Supplement is a letter that explains the qualifications or competence of a certificate issued under the provisions in force, as well as provide information on achievements and awards achieved by student until graduation as stipulated in the Diploma Supplement [8]. Diploma Supplement consists of two pages, the recording sheet student achievement and the pages of information clarifying the description of university level qualifications. Diploma supplement made in English and formally given to all students who graduate with a passive system, which means it will be issued if there is a request from the student. Companion Certificate Diploma is a product/output of student achievement information systems, University of Indonesia (hereinafter referred to as SIPRESMA UI), an information system developed by the University of Indonesia using https://sipresma.ui.ac.id page to support the new policies of University of Indonesia which will issue a Certificate of Companion Certificate together with the certificate when a student graduates from the University of Indonesia. On that page, students can communicate with SIPRESMA UI by entering data about student achievement in several categories. Category prepared is the scientific activities (scientific activities), arts and culture, sports, community services, awards and scholarships, organization and leadership, and so forth. Mechanism SIPRESMA charging data and output of data entry can be seen in the following chart:

SIPRESMA UI used to manage data for a non-academic achievements of students enrolled at the University of Indonesia. More precisely, SIPRESMA UI is an information 


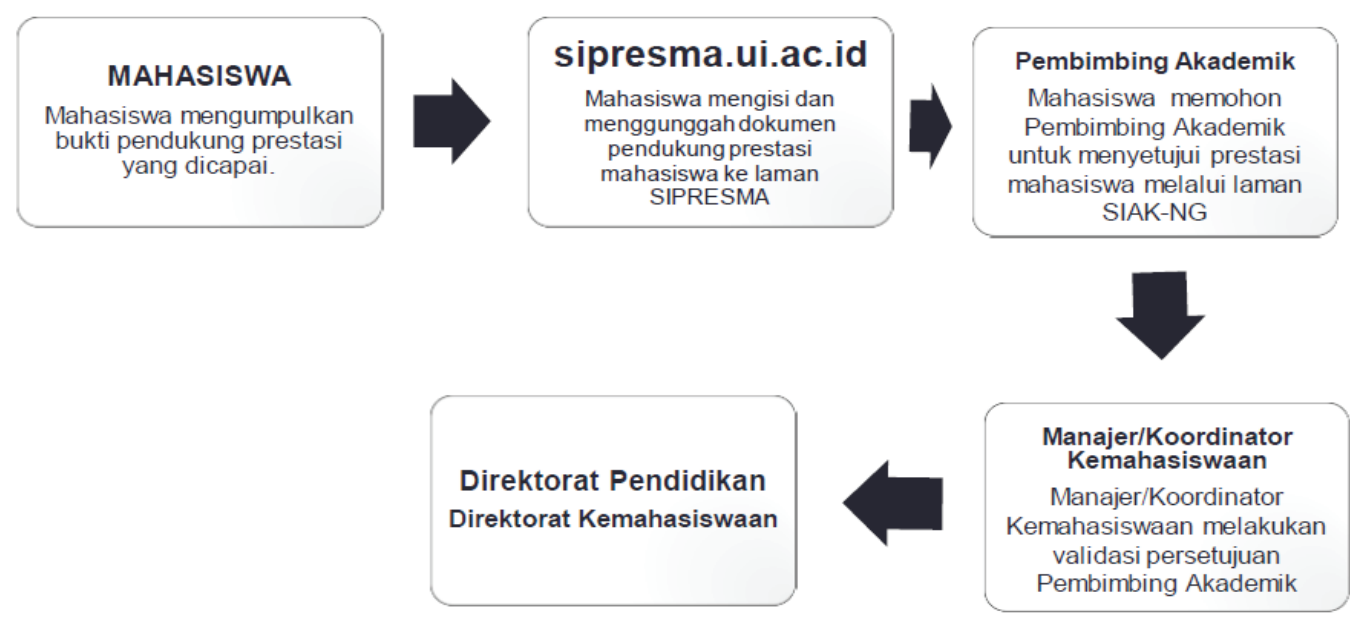

Figure 1: Data entry procedure SIPRESMA. Source: Kurniawan, Edward (2013).

system that manages data in order to support the Diploma Supplement and/or Transcript Student Achievement. The purpose of the issuance of diploma supplement is to provide information on the qualifications or competence acquired diploma students. Moreover, it provides information related to the achievement and student awards earned. While the purpose of publishing the transcripts of student achievement is to provide information recapitulation of student achievement that has been accomplished and to manage data accomplishments and qualifications of prospective graduates.

Although the main task of a student is studying, but activities on campus in addition to formal learning, like experience to join the organization, achievement in specific areas outside the field of academic and work experience, will be very useful for a student when already graduates, and intends to apply for jobs. Currently, the company is not just looking at academic performance prospective employees but also to assess social skills, managerial, and leadership of prospective employees. Information about non-academic achievement can be seen by the employer from Diploma Supplement which is a product of SIPRESMA UI. By reading Diploma Supplement, universities or potential employers can obtain a complete picture of the qualifications of UI graduates.

University of Indonesia already has a system used to manage student achievement data in non-academic named Student achievement information system University of Indonesia (SIPRESMA UI). As a system used in an agency, this system requires socialization to the parties associated with this system so that it can be used properly and meet the expected goals. In SIPRESMA UI, once students enter data accomplishments that have been achieved and from the evidence documents, the students should 
immediately contact the academic supervisor to approve achievement data already inputted into SIPRESMA UI using Role Lecturer on academic information system-next generation (SIAK-NG) held by each academic supervisor. Once approved, Diploma Supplement in hardcopy will be provided by the Directorate of Education UI - a copy can be downloaded at yandok.ui.ac.id- and will be given to the education department of each faculty. In fact, the system is not known by many students, especially new students and the students who have not graduated and also faculty Academic Advisors so that the expected goals of the application UI SIPRESMA is not as expected.

Based on the data obtained by researchers, information systems student achievement, has already been introduced to the students on the student undergoing Initial Activity New Students but it turns out a lot of students do not understand and have not yet realized the usefulness of this information system. Meanwhile, according to information received by investigators, the Administrative Centre of Vocational itself is also already sent a notification letter to the Chairman of the Program to socialize SIPRESMA to lecturers and students but it did not go well because almost all the lecturers still do not know and understand SIPRESMA UI. For students who have just graduated, there is an obligation of the University of Indonesia to fill the track record of students while studying at the University of Indonesia to get a certificate of diploma companion.

From here it is known that socialization SIPRESMA UI to students, faculty, and parties related to it are lacking. In fact, this system will record all non-academic achievements and activities of students from first enrolled in the vocational program until graduation. If students know and be aware of its obligation to include all non-academic achievements and activities to SIPRESMA UI periodically it will be better because it means not to hoard all of this work at one time. Likewise, academic supervisor. But because almost all academic lecturers do not know about this SIPRESMA UI the obligations of the academic supervisor to give approval of the achievement documents that have been uploaded by students is not executed. Finally, diploma supplement cannot be printed for students because it has not been approved by the academic supervisor. Whereas on diploma supplement information will be useful when UI graduates will apply for the job. This information will be taken into consideration for employment agencies to assess social skills, managerial, and leadership of prospective employees.

When viewed closely with Indonesian National Qualifications Framework (KKNI), clearly seen that the information obtained from this in the form SIPRESMA UI Companion Certificate Diploma, in line with the objectives of KKNI. KKNI is a stratification framework qualifications and competence of Indonesian workers who reconcile, 
equalizes, and integrating the education sector by training sector and work experience in a recognition scheme workability adapted to the structure in many employment sectors. KKNI is a stand-alone system and is a bridge between education and training sectors to establish a national human resources qualified and certified through a scheme of formal education, non-formal, informal, job training or work experience.

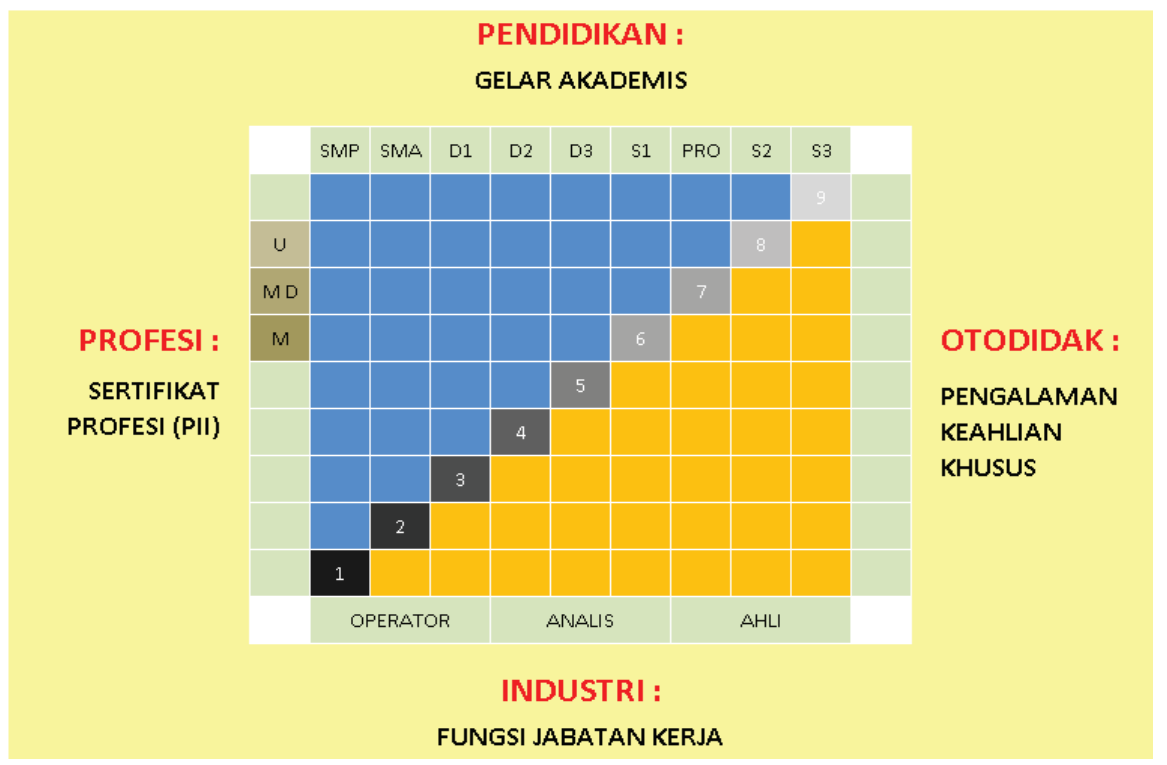

Figure 2: Stratification KKNI through four Roads and combination of all four of them. Source: http://www. penyelarasan.kemdiknas.go.id/content/detail/201.html

With the Certificate of Complementary diploma student achievement can be seen in non-academic fields such as training or certification that has been done, and work experience as well as experience in organization owned by a graduate. Thus the parties concerned with graduates of University of Indonesia mainly Vocational Program University of Indonesia graduates can compare competencies possessed by graduates seen from academic achievement (through certificates) and non-academic (via a letter accompanying diploma) owned by graduates.

In the context of the management of personal archives, SIPRESMA requires students to manage personal archives properly. The problem is, the general public's attention to records-including mahasiswa-still low. It is recorded on the trail Opinion Kompas dated 9 to 10 June 2004 of 990 telephone subscribers in 34 major cities. From these results showed only $35.4 \%$ of respondents said in the habit of making or storing personal or family archives. Nevertheless, 71.9 percent stated how important making or storing personal and family archives. That is, assuming that the archive is important is not accompanied by action to create or save a personal or family archives. Personal archive storage limited only to the aspects of placement records in storage facilities but does not yet reflect a comprehensive archive activities. 
The emphasis of the archive is in terms of rediscovery is not in the storage. Written information is stored for possible use in the future. Archive storage is one of the elements in records management activities. The purpose of the archive management is a series of activities ranging from the archive creation, use and maintenance to depreciation archives. [14]. Awareness for managing personal archives will generate positive habits that take discipline, clean, and precise that personal archive can be instrumental in supporting the activities of life.

Based on the aforementioned problems, the researchers are interested in investigating how is the socialization of SIPRESMA UI done to the students and lecturers of vocational program UI, how are students' perceptions of student achievement information system (SIPRESMA UI), what are the obstacles encountered in the implementation of vocational program SIPRESMA UI in the University of Indonesia and how is the vocational program UI student awareness of the personal filing that will be uploaded to SIPRESMA UI. It is hoped that the results of this research will provide input for Vocational Education Program, University of Indonesia in preparing students to become human beings who have the competence and qualifications based on private non-academic achievement and to improve the management of a private archive for students of vocational program University of Indonesia especially for non-academic achievement archives. Besides, to contribute ideas for the study of students' perceptions of vocational program UI to the Student Achievement Information System University of Indonesia (SIPRESMA UI).

\section{Methodology}

The method used in this study is a quantitative method that aims to reveal the students of vocational program University of Indonesia perception towards the implementation of the Student Achievement Information System University of Indonesia (SIPRESMA UI). The selected objects are students at the Vocational Education Program University of Indonesia, classes of 2013 until 2015. These objects are chosen because we want to know students' perceptions of SIPRESMA UI considering vocational program aims to produce-ready workforce in the industry.

The total sample is 358 divided by the number of courses in proporsioanal. The details are as follows:

Data collection in this study was conducted using questionnaires. Statistical analysis used in the study is univariate system. Univariate analysis is used to see the distribution of answers to each indicator and see the magnitude of score. 
TABLE 1: Number of samples current student Year 2013-2015 in proportion.

\begin{tabular}{|c|c|c|c|c|c|c|c|c|c|c|}
\hline $\mathrm{NO}$ & PROGRAM STUDI & 2013 & $\begin{array}{c}\text { Jumlah } \\
\text { sampel } \\
(\%)\end{array}$ & $\begin{array}{c}\text { Jumlah } \\
\text { sampel } \\
\text { (desi- } \\
\text { mal) }\end{array}$ & 2014 & $\begin{array}{c}\text { Jumlah } \\
\text { sampel } \\
(\%)\end{array}$ & $\begin{array}{c}\text { Jumlah } \\
\text { sampel } \\
\text { (desi- } \\
\text { mal) } \\
\end{array}$ & 2015 & $\begin{array}{c}\text { Jumlah } \\
\text { sampel } \\
(\%)\end{array}$ & $\begin{array}{c}\text { Jumlah } \\
\text { sampel } \\
\text { (desi- } \\
\text { mal) } \\
\end{array}$ \\
\hline 1 & Komunikasi & 171 & $32.14 \%$ & 18 & 217 & $40.79 \%$ & 23 & 144 & $27.07 \%$ & 15 \\
\hline 2 & Pariwisata & 105 & $36.59 \%$ & 11 & 114 & $39.72 \%$ & 12 & 68 & $23.69 \%$ & 7 \\
\hline 3 & Fisioterapi & 68 & $52.71 \%$ & 7 & 34 & $26.36 \%$ & 4 & 27 & $20.93 \%$ & 3 \\
\hline 4 & Okupasi Terapi & 43 & $44.79 \%$ & 4 & 28 & $29.17 \%$ & 3 & 25 & $26.04 \%$ & 3 \\
\hline 5 & Perumahsakitan & 155 & $38.46 \%$ & 16 & 176 & $43.67 \%$ & 18 & 72 & $17.87 \%$ & 8 \\
\hline 6 & $\begin{array}{l}\text { Adm. Asuransi dan } \\
\text { Aktuaria }\end{array}$ & 51 & $23.72 \%$ & 5 & 86 & $40.00 \%$ & 9 & 78 & $36.28 \%$ & 8 \\
\hline 7 & $\begin{array}{l}\text { Adm. Keuangan dan } \\
\text { Perbankan }\end{array}$ & 81 & $28.32 \%$ & 9 & 119 & $41.61 \%$ & 13 & 86 & $30.07 \%$ & 9 \\
\hline 8 & $\begin{array}{l}\text { Adm. Perkantoran dan } \\
\text { Sekretari }\end{array}$ & 106 & $34.08 \%$ & 11 & 127 & $40.84 \%$ & 13 & 78 & $25.08 \%$ & 8 \\
\hline 9 & $\begin{array}{l}\text { Manajemen Informasi } \\
\text { dan Dokumen }\end{array}$ & 67 & $26.27 \%$ & 7 & 116 & $45.49 \%$ & 12 & 72 & $28.24 \%$ & 8 \\
\hline 10 & Administrasi Perpajakan & 133 & $38.55 \%$ & 14 & 140 & $40.58 \%$ & 15 & 72 & $20.87 \%$ & 8 \\
\hline 11 & Akuntansi & 154 & $28.73 \%$ & 16 & 219 & $40.86 \%$ & 24 & 163 & $30.41 \%$ & 17 \\
\hline & Jumlah & 1134 & $100 \%$ & 118 & 1376 & $100 \%$ & 146 & 885 & $100 \%$ & 94 \\
\hline
\end{tabular}

\section{Result and Discussion}

\subsection{Characteristics of respondents}

The respondents were students at Vocational Education Program University of Indonesia classes of 2013 until 2015.

TABLE 2: Respondents' Gender. ( $L=$ Male, $P=$ Female $)$

\begin{tabular}{|c|l|c|c|c|c|c|c|}
\hline \multirow{2}{*}{ NO } & \multirow{2}{*}{ PROGRAM STUDI } & \multicolumn{2}{|c|}{$\mathbf{2 0 1 3}$} & \multicolumn{2}{c|}{$\mathbf{2 0 1 4}$} & \multicolumn{2}{c|}{$\mathbf{2 0 1 5}$} \\
\cline { 2 - 8 } & L & P & L & P & L & P \\
\hline 1 & Komunikasi & 1 & 17 & 8 & 15 & 2 & 13 \\
\hline 2 & Pariwisata & 4 & 7 & 4 & 8 & 4 & 3 \\
\hline 3 & Fisioterapi & 1 & 6 & 0 & 4 & 2 & 1 \\
\hline 4 & Okupasi Terapi & 1 & 3 & 0 & 3 & 0 & 3 \\
\hline 5 & Perumahsakitan & 6 & 10 & 7 & 11 & 3 & 5 \\
\hline 6 & Adm. Asuransi dan Aktuaria & 3 & 2 & 4 & 5 & 6 & 2 \\
\hline 7 & Adm. Keuangan dan Perbankan & 3 & 6 & 0 & 13 & 4 & 5 \\
\hline 8 & Adm. Perkantoran dan Sekretari & 3 & 8 & 4 & 9 & 2 & 6 \\
\hline 9 & Manajemen Informasi dan Dokumen & 2 & 5 & 7 & 5 & 2 & 6 \\
\hline 10 & Administrasi Perpajakan & 8 & 6 & 4 & 11 & 3 & 5 \\
\hline 11 & Akuntansi & 5 & 11 & 8 & 16 & 10 & 7 \\
\hline & & 37 & 81 & 46 & 100 & 38 & 56 \\
\hline
\end{tabular}


The respondents from Table 2 are from 11 courses with the following details.

TABLE 3: Studies program respondents.

\begin{tabular}{|c|c|c|c|c|c|}
\hline No. & Program Studi & 2013 & 2014 & 2015 & Total \\
\hline 1 & Komunikasi & 18 & 23 & 15 & 56 \\
\hline 2 & Pariwisata & 11 & 12 & 7 & 30 \\
\hline 3 & Fisioterapi & 7 & 4 & 3 & 14 \\
\hline 4 & Okupasi Terapi & 4 & 3 & 3 & 10 \\
\hline 5 & Perumahsakitan & 16 & 18 & 8 & 42 \\
\hline 6 & Adm. Asuransi dan Aktuaria & 5 & 9 & 8 & 22 \\
\hline 7 & Adm. Keuangan dan Perbankan & 9 & 13 & 9 & 31 \\
\hline 8 & Adm. Perkantoran dan Sekretari & 11 & 13 & 8 & 32 \\
\hline 9 & Manajemen Informasi dan Dokumen & 7 & 12 & 8 & 27 \\
\hline 10 & Administrasi Perpajakan & 14 & 15 & 8 & 37 \\
\hline \multirow[t]{2}{*}{11} & Akuntansi & 16 & 24 & 17 & 57 \\
\hline & Total & 118 & 146 & 94 & 358 \\
\hline
\end{tabular}

\subsection{Univariate analysis results}

Univariate analysis was conducted to determine the distribution of answers to each indicator and see the magnitude of score. The results are as follows.

Based on the data obtained from the aforementioned table, the outline can be presented major findings obtained are:

- The study was conducted to see how students' perceptions of application SIPRESMA UI UI in the vocational program.

- Data were obtained from students active for class of 2013, 2014, and 2015 are derived from the 11 existing courses in the vocational program Ul.

- Approximately $55.03 \%$ of the students quite agree that they never heard of SIPRESMA UI.

- Approximately $52.96 \%$ of the students disagreed that they obtain sufficient information about SIPRESMA UI from other sources (friends, internet, and other media).

- Approximately $52.46 \%$ of the students disagreed that they obtain sufficient information about SIPRESMA UI from Vocational Education Officer.

- Approximately $49.83 \%$ of the students disagreed that they obtain sufficient information about SIPRESMA UI from the chairman of the program, respectively.

- Approximately $49.11 \%$ of the students agreed that they obtain sufficient information about SIPRESMA UI from the Studies Student Association. 
TABLE 4: Results of univariate analysis.

\begin{tabular}{|c|c|c|c|c|c|c|}
\hline No. & Questions/ Indicators for & $\begin{array}{l}\text { Strongly } \\
\text { Disagree } \\
\quad(\%)\end{array}$ & $\begin{array}{c}\text { Disagree } \\
(\%)\end{array}$ & $\begin{array}{l}\text { Quite } \\
\text { Agree } \\
(\%)\end{array}$ & $\begin{array}{c}\text { Agree } \\
(\%)\end{array}$ & $\begin{array}{l}\text { Strongly } \\
\text { agree } \\
(\%)\end{array}$ \\
\hline 1 & Never heard about SIPRESMA UI & 16.8 & 33.5 & 19.3 & 18.7 & 11.7 \\
\hline 2 & $\begin{array}{l}\text { Obtaining information about SIPRESMA UI at new students } \\
\text { activities }\end{array}$ & 19.0 & 41.9 & 20.9 & 14.8 & 3.4 \\
\hline 3 & $\begin{array}{l}\text { Obtaining information about SIPRESMA UI from Officer of } \\
\text { Vocational Education Program University of Indonesia. }\end{array}$ & 15.6 & 38.5 & 20.1 & 19.3 & 6.4 \\
\hline 4 & $\begin{array}{l}\text { Obtaining information about SIPRESMA UI from Chairman of } \\
\text { the Program Study }\end{array}$ & 17.0 & 41.3 & 20.4 & 16.5 & 4.5 \\
\hline 5 & $\begin{array}{l}\text { Obtaining information about SIPRESMA UI from Student } \\
\text { Executive Board Vocational Education Program University of } \\
\text { Indonesia. }\end{array}$ & 21.5 & 40.8 & 19.6 & 14.2 & 3.4 \\
\hline 6 & $\begin{array}{l}\text { Obtaining information about SIPRESMA UI from Student } \\
\text { Association Vocational Education Program University of } \\
\text { Indonesia. }\end{array}$ & 18.7 & 40.2 & 21.5 & 15.9 & 3.6 \\
\hline 7 & $\begin{array}{l}\text { Obtaining information about SIPRESMA UI from other sources } \\
\text { (friends, internet, other media) }\end{array}$ & 15.6 & 33.8 & 23.5 & 21.5 & 5.0 \\
\hline 8 & $\begin{array}{l}\text { Knowing the output of SIPRESMA UI is the companion diploma } \\
\text { (Diploma Supplement). }\end{array}$ & 10.1 & 32.7 & 25.1 & 24.0 & 7.3 \\
\hline 9 & $\begin{array}{l}\text { Knowing the right of every college graduates according to the } \\
\text { minister of Education and Culture Regulation } 81 \text { of } 2014 \text { on the } \\
\text { certificate, Certificate of Competency and Certificate of } \\
\text { Professional Education Article } 5\end{array}$ & 9.2 & 26.3 & 19.0 & 35.5 & 9.5 \\
\hline 10 & $\begin{array}{l}\text { Knowing that the output of SIPRESMA UI is a diploma } \\
\text { supplement that is the result of recording student achievement in } \\
\text { the field of non-academic }\end{array}$ & 9.5 & 28.2 & 26.8 & 27.9 & 7.5 \\
\hline 11 & $\begin{array}{l}\text { Knowing to get a diploma supplement the student must enter the } \\
\text { student's achievement in non-academic fields through pages } \\
\text { https://sipresma.ui.ac.id }\end{array}$ & 12.3 & 31.0 & 21.2 & 27.4 & 8.1 \\
\hline 12 & $\begin{array}{l}\text { Knowing after inputting / recording documents the achievements } \\
\text { in the field of non-academic student must bring the original } \\
\text { documents to the academic supervisor for verification. }\end{array}$ & 10.1 & 31.8 & 22.3 & 25.7 & 8.9 \\
\hline 13 & $\begin{array}{l}\text { Knowing the diploma supplement is important for helping to make } \\
\text { it easier to get a job in accordance with the competence of } \\
\text { graduates }\end{array}$ & 6.4 & 15.6 & 21.5 & 39.4 & 17.0 \\
\hline 14 & $\begin{array}{l}\text { Diploma supplement is important that students must follow the } \\
\text { activities in the field of non-academic }\end{array}$ & 5.3 & 14.0 & 28.2 & 35.2 & 17.3 \\
\hline 15 & $\begin{array}{l}\text { After obtaining a certificate or a certificate of non-academic } \\
\text { activities that is followed, students must file the document. }\end{array}$ & 3.9 & 12.0 & 22.6 & 38.3 & 22.9 \\
\hline 16 & $\begin{array}{l}\text { Certificate or certificate obtained should be classified based on the } \\
\text { chronological order or the subject of activity. }\end{array}$ & 3.9 & 10.9 & 27.4 & 43.3 & 14.0 \\
\hline 17 & $\begin{array}{l}\text { Certificate or certificate obtained must be stored physically in a } \\
\text { particular storage area (folder or special folder). }\end{array}$ & 4.2 & 9.8 & 20.4 & 41.9 & 22.9 \\
\hline 18 & $\begin{array}{l}\text { Certificate obtained must be stored physically in a particular } \\
\text { storage area (folder or special folder). }\end{array}$ & 3.4 & 13.4 & 21.2 & 39.1. & 21.8 \\
\hline 19 & $\begin{array}{l}\text { One of the obstacles in the implementation of SIPRESMA UI } \\
\text { vocational program is the management of personal records that are } \\
\text { less / not good that the evidence is not complete to be uploaded to } \\
\text { SIPRESMA UI. }\end{array}$ & 5.6 & 17.3 & 31.0 & 33.0 & 11.5 \\
\hline 20 & $\begin{array}{l}\text { Another constraint indicator on the application SIPRESMA UI is } \\
\text { the awareness of students to manage personal records it is still } \\
\text { lacking. }\end{array}$ & 5.0 & 17.6 & 25.1 & 33.0 & 18.2 \\
\hline
\end{tabular}

- Approximately $48.32 \%$ of the students agreed that they obtain sufficient information about SIPRESMA UI when they were in initial activities as new student.

- Approximately $47.09 \%$ of the students agreed that they obtain sufficient information about SIPRESMA UI from Student Executive Board.

- Approximately $74.03 \%$ of the students agreed that the certificate obtained must be stored physically in a particular storage area (folder or special folder). 
- Approximately $72.89 \%$ of the students agreed that after obtaining a certificate of non-academic activities that followed, students must file the document.

- Approximately $72.66 \%$ of the students agreed that the certificate obtained must be scanned in order to be saved in softcopy and stored in a specific folder.

- Approximately $70.56 \%$ of the students agreed that the certificate obtained should be classified based on the chronological order or the subject of activity.

- Approximately $69.05 \%$ of the students agreed that the diploma supplement is important that students must follow the activities in the field of non-academic.

- Approximately $68.99 \%$ of the students agreed that they knew diploma supplement is important to help them easier to get a job in accordance with the competence of graduates.

- Approximately $68.42 \%$ of the students agreed that the existing constraints in the implementation of SIPRESMA UI for students of Vocational program is the awareness of students to manage personal records it is still lacking.

- Approximately $65.57 \%$ of the students agree that one of the obstacles in the implementation of SIPRESMA UI for students of vocational program is the management of personal records that are less/not good that the evidence of nonacademic achievements is not complete to be uploaded to SIPRESMA UI.

- Approximately $61.97 \%$ of the students agreed that they knew the right of every college graduates according to the minister of Education and Culture Regulation 81 of 2014 Article 5 about the certificate, Certificate of Competency and Certificate of Professional Education.

- Approximately $59.16 \%$ of the students agreed that they know the output of SIPRESMA UI is a diploma supplement that is of recording student achievement in the field of non-academic.

- Approximately $58.31 \%$ of the students agreed that they knew recording achievement documents in the field of non-academic student must bring the original documents to the academic supervisor for verication.

- Approximately $57.60 \%$ of the students agreed that they know to get the diploma supplement they must input the achievements documents of non-academic fields through pages https://sipresma.ui.ac.id.

- Approximately $57.13 \%$ of the students agreed that they know the output of SIPRESMA UI is the companion diploma (Diploma Supplement). 


\subsection{Discussion}

Based on data obtained from the aforementioned table shows that the students generally know less about student achievement information system University of Indonesia. The average student does not agree that they had obtained information about student achievement information system both from the University of Indonesia Vocational Education Officer, chairman of the program, Student Association, Student Executive Board, and other sources (friends, internet, other media). This means socialization conducted vocational program on student achievement information system of the University of Indonesia was less successful.

The students also did not know that the output of student achievement information systems, University of Indonesia is a diploma supplement that can assist them in finding jobs after graduation. The students do not know that the input of the system is a document student achievement obtained after following non-academic activities. This condition is a good input for Vocational Education Program, University of Indonesia in order to socialize as well as greater attention on this issue given that the Vocational Education Program, University of Indonesia aims to produce a ready workforce in the industry.

But the students realized that the diploma supplement is important and can help them to make it easier to get a job after graduation. They also realize there is an obligation to archive documents/certificates of non-academic achievements in a special folder and are arranged in chronological order. Lack of documents/certificates owned non-academic activities as well as the lack of awareness in the practice of personal archiving. It can also be input for Vocational Education Program, University of Indonesia to always remind students to participate in non-academic activities on campus and reminds the importance of managing personal archives. Thus, the purpose of Vocational Education Program, University of Indonesia in order to produce a ready workforce in the industry can be achieved.

\section{Conclusion}

The result of this study shows that the highest score achieved by several indicators, namely ever heard of SIPRESMA UI (55.03\%), obtaining Information about SIPRESMA UI from other sources (53.26\%) and Obtaining Information from the UI SIPRESMA KPS, respectively (52.46\%). The lowest score is no indicator of Information SIPRESMA of Student Executive Board (47.36\%) as well as obtaining Information about SIPRESMA 
Ul from new students activities (48.32\%). These results This result is very significant input for Vocational Education Program, University of Indonesia

\section{Recommendations}

SIPRESMA UI needs to be disseminated through:

1. Student Executive Board Vocational Education Program, University of Indonesia

2. Activities for new students

3. Student Association

It is also important to socialize the output of SIPRESMA UI is a companion certificate/diploma supplement as well as dissemination is also necessary to get a diploma supplement that students should enter the certificate in non-academic fields through pages https://sipresma.ui.ac.id

\section{Acknowledgment}

The authors would like to thank the Vocational Education Program University of Indonesia, Depok, Indonesia, for supporting the study.

\section{References}

[1] Bryman, Alan (2008). Social Research Methods Third Edition. New York: Oxford University Press.

[2] Chaplin, J. P. (2008). Kamus Lengkap Psikologi. Jakarta : PT Raja Grafindo Persada.

[3] Ciccarelli. S., and Meyer.G. (2006) Psychology. New Jersey: Pearson Education

[4] Giatrininggar. Esti. (2012) Persepsi Mahasiswa FIB UI terhadap Surat keputusan rektor nomor 1805/SK/R/UI/2011 tentang kawasan tanpa rokok (KTR) Universitas Indonesia Tahun 2012. Diambil 30 Maret 2016 dari www.lib.ui.ac.id/file?file=pdf/ abstrak-20313535.pdf

[5] Kemendiknas. (2016) Kerangka Kualifikasi Nasional Indonesia. Diambil 30 Maret 2016.

[6] http://www.penyelarasan.kemdiknas.go.id/content/detail/201.html

[7] Ghozali, Imam (2005). Aplikasi Analisis Multivariat Dengan Program SPSS Edisi Ketiga. Semarang: Badan Penerbit Universitas diponegoro 
[8] Kurniawan, Edward (2013). Sistem Informasi Prestasi Mahasiswa Ul. Disampaikan pada Rapat Kerja Bidang Kemahasiswaan UI. Yogyakarta 28-29 Maret 2013.

[9] Kriyantono, Rakhmat (2010). Teknik Praktis Riset Komunikasi. Jakarta: Kencana.

[10] Kotler, Phillip (1995). Marketing Management Analysis, Planning, Implementation\& Control. New Jersey : Prentice Hall Inc.

[11] Nasution, S. (2000). Metode Research. Jakarta: Bumi Aksara.

[12] Mishra, Rajan. (2008). Industrial Economic and Management Principles. New Delhi: Laxmi Publication Ltd.

[13] Robbins, Stephen P. (2003). Perilaku organisasi. Jakarta : PT. Indeks Kelompok Gramedia

[14] Samadikun, Mas Yanto (2013). Tata Kelola Arsip Keluarga : Sebuah Pengalaman Pribadi. Jurnal Khazanah Arsip Universitas Gadjah Mada Vol. 6 no.2. July $2013: 22$ $-34$

[15] Sugiyono (2012). Metode Penelitian Bisnis. Bandung : Penerbit Alfabeta.

[16] Thoha. Miftah. (2013). Perilaku Organisasi:Konsep Dasar dan Aplikasinya Edisi 1. Jakarta : Raja Grafindo Persada. 